\title{
SUMBER SANSEKERTA TEKS SIWARATRIKALPA
}

\author{
I Nyoman Raka \\ STAHN Mpu Kuturan Singaraja,
}

\begin{abstract}
Abstrak
Teks Siwaratrikalpa seringkali dijadikan bahan diskusi, rujukan pelaksanaan brata siwaratri terutama oleh masyarakat Hindu di Bali maupun di Lombok. Diskusi tentang siwaratrikalpa seringkali menyisakan berbagai pertanyaan di seputar implikasi pelaksanaan brata siwaratri. Sejumlah pertanyaan yang dimaksud antara lain: apakah dosa bisa ditebus? Apakah tokoh Lubdaka itu papa atau dosa? Apakah Mpu Tan Akung pengarang cerita Lubdaka untuk tujuan mengambil hati Ken Arok?, Apakah cerita Lubdhaka ciptaan Mpu Tanakung?; Apa fungsi cerita Lubdhaka dalam konteks hari suci Śiwaratri?; Bagaimanakah pelaksanaan brata Šiwaratri sesuai dengan tuntunan kitab suci. Sederet pertanyaan ini adalah pertanda pentingnya penelitian tentang teks Siwaratri.

Guna menerangjalaskan jawaban pertanyaan di di atas, akan diteliti sejumlah sumber Sanskerta, maupun kawi terkait dengan teks Siwaratrikalpa. Penelitian ini memakai pendekatan studi teks, baik teks Purana, maupun teks berbahasa Kawi. Dua sumber ini diharapkan dapat menerangjelaskan pertanyaan di atas.

Penelusuran sejumlah sumber Sanskreta menemukan, empat purana terkait dengan teks Siwaratrikalpa. Empat purana yang dimaksud adalah: Padma Purāņa, Šiwa Purāna, Skanda Purāna dan Garuda Purāna. Esensi empat purana ini menjelaskan kekejaman, kekilapan, seorang penjahat yang berujung pertobatan, dapat mengantarkan pencapaian kebenaran. Kesadaran dan pertobatan dapat mengembalikan manusia pada jalan kebenaran mencapai alam Siwa, adalah esensi ajaran brata Siwaratri.
\end{abstract}

Keywords: sanskreta, pertobatan, kebenaran

\section{PENDAHULUAN}

Kakawin siwaratrikalpa memuat ajaran Śiwa. Sembah dan persembahan ke hadapan Dewa Šiwa menjadi ajaran pokok kakawin ini. "Pertemuan" dan "Persatuan" dengan Śiwa adalah tujuan akhir mazab ini. Dalam mencapai tujuan agama, ada tatacara (berkaitan dengan etika dan upacara) yang harus dilaksanakan oleh penganut suatu agama. Kitab kakawin siwaratrikalpa menjadikan cerita Lubdaka sebagai tata cara mencapai tujuan agama penganut siwaisme.

Dalam konteks siwaratrikalpa, ringkasan cerita Lubdhaka, adalah tata cara, adalah etika yang dapat dipedomani untuk mencapai tujuan agama masab siwa. Cerita Lubdaka dicontohkan dalam teks siwaratrikalpa, bahwa si Lubdaka, pada awal cerita digambarkan sebagai pembunuh, namun telah melaksanakan brata Siwaratri; melakukan pajagran atau tidak tidur, tan aturu, tan mrema, atanghi atau atutur, pada saat yang tepat, maka dapat mencapai alam Siwa.

Logika ajaran, pendidikan, pencapaian alam siwa seperti ini seringkali dipertanyakan dalam diskusi malam siwa. Apakah hanya dengan melaksanakan jagra semalam suntuk dapat menghapus dosa? Bagaimana dengan logika ajaran karma phala? Yang dengan jelas mangajarkan bahwa karma 
menentukan phala. Karma baik dapat berphala baik, sedangkan karma buruk akan berphala buruk.

Kalau dilihat dari fungsi teks sastra, mendidik dan menghibur adalah salah satu fungsi karya sastra. Fungsi mendidik karena dalam setiap karya sastra itu selalu memiliki amanat, atau pesan moral yang ingin disampaikan oleh pengarang kepada pembaca. Pesan moral inilah nilai pendidikan yang tersurat maupun tersirat di dalam karya sastra. Kemudian manakala nilai pendidikan pencapaian alam siwa dipertanyakan, inilah yang menimbulkan diskusi panjang saat merayakan malam siwa.

Kalau dibandingkan dengan cerita rakyat berjudul Men Tiwas dan Men Sugih, fungsi didaktis cerita rakyat ini sangat jelas. Melalui alur cerita yang sangat sederhana pengarang mengajarkan kejujuran kepada pembaca cerita, yang dengan sederhana dapat diilustrasikan sebagai berikut.

Men tiwas karena miskinnya diceritakan menangis di tengah hutan, saat mencari kayu bakar, kemudian datang seekor kijang mas, seraya menyuruh men tiwas memasukan tangannya ke lobang anus di kidang tersebut. Tanpa berpikir panjang Men Tiwas melakukannya, dan saat tangannya ditarik dari pantat kidang itu maka yang ia dapatkan adalah sejumlah perhiasan emas. Pemakaian perhiasan emas bagi keluarga Men Tiwas, dapat meningkatkan status sosial Men Tiwas di masyarakat.

Mendengar peningkatan status sosial keluarga Men Tiwas yang meningkat, Men Sugih menjadi iri hati seraya bertanya kepada Men Tiwas, Dimana dapat perhiasan emas sejumlah itu? Dengan jujur, Men tiwas menceritakan kronologi perolehan emas kepada Men Sugih. Keseokan harinya 61
Men Sugih melakukan hal serupa dengan yang dilakukan Men Tiwas; pergi ke hutan bertemu seekor kijang, kemudian disuruh memasukan tangannya ke lobang anus si kidang, tapi apa yang terjadi? Men Sugih diseret oleh si kidang sampai luka-luka di sekujur tubuhnya, dan tidak mendapatkan emas seperti yang didapatkan oleh Men Tiwas.

Cuplikan ilustrasi cerita Men Tiwas dan Men Sugih ini bermakna mendidik, yakni mengandung fungsi pendidikan kejujuran. Barang siapa jujur seperti Men Tiwas akan mendapatkan perhiasan emas, barang siapa yang serakah, berpura-pura miskin seperti Men Sugih akan mendapat hukuman, diseret kidang. Fungsi pendidikan dalam cerita Men Tiwas dan Men Sugih ini, tak terbantahkan sebagai pendidikan etika. Harapan pengarang kepada pembaca ceritanya adalah munculnya sikap dan perilaku jujur seperti Men Tiwas, dan tidak mengambangkan sikap dan perilaku berpura-pura seperti Men Sugih.

Fungsi menghibur sebuah karya sastra tidak kalah penting. Karena fungsi mendidik, jika tidak disampaikan dengan cara menghibur, bisa ditinggalkan oleh pembaca. Peran fungsi penghiburan, dalam setiap karya sastra menjadi penting diperhatikan. Dengan fungsi penhiburan yag baik, pembaca menjadi semakin tertarik dan mungkin ketagihan membaca cerita sampai selesai.

Fungsi mendidik dan menghibur berlaku pada karya sastra lubdaka cerita, dalam teks kakawin Siwaratrikalpa. Fungsi pendidikan yang dimaksud adalah fungsi pendidikan spiritual, guna dapat mencapai alam sorga; yang dalam kontek teks kakawin siwaratrikalpa dikenal dengan istilah mencapai alam siwa.

Logika pendidikan pencapaian alam siwa yang dilakukan oleh Tokoh 
Lubdaka, mengundang pertanyaan awam, manakala dibandingkan dengan logika ajaran karma phala dalam ajaran agama Hindu. Alur cerita seorang pembunuh, yang karena melaksanakan brata siwaratri, kemudian dikatakan bisa mencapai alam siwa dipandang kurang logis diterima oleh logika orang awam yang bersifat kritis.

Orang yang berpaham keyakinan bisa saja meyakini kebenaran teks siwaratrikalpa sebagai sebuah kebenaran. Orang orang seperti ini biasanya dengan tekun melakukan brata siwaratri untuk tujuan mendapat menghapus perbuatan buruknya agar berphala baik. Namun akan sangat berbeda halnya dengan masyarakat yang berpikiran kritis. Kelompok masyarakat ini akan menolak kebenaran logika pendidikan, tokoh Lubdaka yang pada awalnya dikenal sebagai pembunuh kemudian karena melakukan brata siwaratri kemudian bisa mencapai alam siwa. Karena logika ajaran karma phala menjelaskan bahwa perbuatan membunuh binatang dikatagorikan sebagai dosa, sehingga tidak mungkin bisa masuk surga karena brata siwaratri. Karena logika berpikir yang kurang masuk akallah, memunculkan alasan untuk menyebut teks Siwaratrikalpa bersifat propokatif.

Guna dapat menerangjelaskan logika pembunuh bisa masuk surga, dipandang penting melakukan penelitian terhadap sejumlah sumber sastra, baik sumber saskreta maupun sumber berbahasa Kawi. Secra teknik penelurusan ini memakai pendekatan studi pustaka, yakni dengan membanding-banding sejumlah pustaka terkait, meneliti semua variabel yang ada, mengaitkan sejumlah unsur variabel dan menemukan kemungkinan kebenaran dan kesalahan yang mungkin terjadi sebagai hasil analisis variabel.

\section{PEMBAHASAN 2.2 Padma Purāṇa}

Ajaran agama yang terkandung dalam teks Šiwaratri adalah ajaran Śiwa. Sembah dan persembahan ke hadapan Šiwa sebagai Tuhan Pengasih dan Mahaagung sudah pasti menjadi ajaran pokok di dalamnya. "Pertemuan" dan "persatuan" dengan Śiwa adalah menjadi tujuan akhir pemeluk ajaran ini, (Sudarta, 1991: 5).

Penelusuran sejumlah purana menemukan empat purana yang memiliki relevansi dengan teks Siwaratri, yakni: Padma Purāņa, Šiwa Purāna, Skanda Purāna dan Garuda Purāna. Ke dalam empat purana ini menguraikan tentang, upacara siwaratri, sampai dengan uraian si Lubdaka sebagai seorang pemburu, sekaligus seorang pembunuh binatang, yang karena ketakunan dalam melaksanakan brata siwaratri pada malam siwa, akhirnya berhasil masuk sorga, yang tiada lain karena mendapat anugerah Siwa di Šiwa loka.

Dalam Padma Purana, dan Kakawin Šiwaratrikalpa Lubdaka dinyatakan sebagai orang yang papa; di dalam teks ini pengarang tidak memakai istilah dosa. Šiwaratri vinjneya sarvapāpapaharini (239:3), kaka papa berkali-kali dipakai susunan kata yang sama, yaitu tesam pāpāni nasyanti sivaratriprajagarat (204:45, 48, 49, 50, 51, 52, 55). Dalam kakawin Siwaratrikalpa ditulis: ikang makangaran si Lubdhaka juga ng huwus angulahaken warabratal matanghi rikanang wenging kapitu makatithi caturdasottamal (34, 5a, b) sapāpa nika 
sirna de ni phala ning brata winuwusakenku tan salah (34, 4d). Bagaimana konsep ajaran Siwa tentang istilah: atanghi, turu (tidur) dan pāpa? Menjadi fungsi didaktis, fungsi pendidikan kakawin Siwaratrikalpa.

Orang sangat mungkin menjadi papa, menjadi sangat hida dina, akan tapi hendaknya jangan menjadi dosa. Dosa adalah predikat yang diberikan kepada orang yang melangar norma, aturan kehidupan. Men Tiwas bisa disebut orang papa, orang miskin, tidak akan berdosa manakala ia harus memetik dan mencabut sayur mayur untuk kepentingan dikonsumsi keluarga guna dapat mempertahankan hidupnya. Memetik dan mencabut tanaman sayur adalah bukan perbuatan dosa, melainkan tata cara mempertahankan hidup.

Dalam mencapai tujuan, ada tatacara, biasanya berkaitan dengan etika dan upacara, yang dijadikan tahapan dalam mencapai tujuan. Ringkasan cerita Lubdaka dalam teks Siwaratrikalpa adalah etika Lubdaka mencapai alam siwa. Melaksanakan brata siwaratri pada malam siwa adalah tata cara mencapai alam siwa. Istilah jagra, tidak tidur semalam suntuk, tan aturu, tan mrema, atanghi atau atutur adalah istilah klasik, yang syarat makna dalam Kakawin Šiwaratrikalpa namun masih perlu didiskusikan sampai menemukan logika spiritualnya.

Relevansi teks siwaratrikalpa dengan teks Padmapurāna, terlihat dalam percakapan Raja Dilipa dengan Rsi Wasistha. Kata "lubdhaka" (Bahas Sanskreta) artinya 'pemburu'. Kata ini dipakai dua kali dalam konsteks kalimat: niraso lubdhaka tlathad yavad astam gato ravih (37a) dan tasya gadham samasadya lubdhakasya varanane (42b). dan kata Lubdaka ini juga dijadikan tokoh utama dalam kakawin siwaratrikalpa karya Mpu Tanakung. Dalam Padma purāṇa, juga diuraikan ajaran brata Šiwaratri, dan ritual atau tata pelaksanaannya. Ajaran inilah menjadi esensi ajaran yang disampaikan oleh Dewa Śsiwa kepada Dewi Uma, sekaligus menjadi inti sari jaran di dalam kakawin Siwaratrikalpa.

P. Worsley (1969) salah seorang peneliti purana dan sastra kakawin Siwaratrikalpa menjelaskan, bahwa Padmapurān,a adalah contoh yang paling dekat dengan kisah Lubdaka dalam kakawin Siwaratrikalpa. Ia mencatat bahwa "dalam beberapa kasus ditemukan kemiripan yang sangat mencolok antara Padma Purana dengan kakawin siwaratrikalpa, bahkan seolaholah berhadapan dengan sebuah terjemahan". Worsly menyebut, In some cases the similarities are strickngly close and in one or two places could be called translation.

Senada dengan Worsley, Zoetmulder yang juga membandingkan padma Purana dengan teks kakawin Siwaratrikalpa berpendapat, bahwa mutu cerita Lubdaka dalam teks siwaratrikalpa bertambah bagus, setelah digubah oleh seorang penyair Jawa Kuno yang bernama $\mathrm{Mpu}$ Tanakung, menjadikannya sebuah karya sastta kakawin. Worsley dan Zoetmulder sepakat, bahwa Mpu Tanakung mahakawi besar yang senantiasa "merindukan keindahan" mahakawi yang amat sangat "dramatis pesona", sekaligus misterius di mata peneliti.

Disebut mistirius karana sampai saat ini belum ada kepastian masa hidup seorang $\mathrm{Mpu}$ Tanakung yang sesungguhnya. Banyak peneliti melahirkan penafsiran yang beragam tentang kehidupan Mpu Tanakung, 
artinya masih ada beragam pandangan tentang masa hidup Mpu Tan akung. Di satu sisi ada yang menyebut beliau hidup dua setengah abad pasca kerajaan majapahit, di sisi lain ada yang mengatakan hidup pada jaman Majapahit akhir.

Munculnya pandangan bahwa karya kakawin Siwaratrikalpa diciptakan oleh Mpu Tanakung untuk tujuan mengambil hati raja Ken Arok, disebabkan oleh penafsiran yang menyebutkan, bahwa karya sastra Lubdhaka yang digubah oleh Mpu Tanakung, yang hidup selama pemerintahan Ken Angrok, ketika kraton dipindah dari Kediri ke Tumapel, tahun Saka 1144 (1222 sesudah Masehi). Perbedaan penafsiran atas kehadiran mahakawi Mpu tanakung, menantang peneliti sastra kawi, guna dapat menafsirkan MpuTankung dengan lebih mendekati sempurna.

Kesamaan lain antara naskah Padmapurāna dengan teks Siwaratrikalpa, yang menjadi intisari percakapan antara Maharsi Wasiştha dengan raja Dilipa adalah sebagai berikut:

$\begin{array}{lr}\text { 1. Śrnu rājan } & \text { prayaksyāmi } \\ \text { śivaratrivratam taya vratānān } \\ \text { uttanan } & \text { sāksāe }\end{array}$

chivalekaikasādhänam,

artinya,

Wahai baginda raja, simaklah dengan seksama, hamba akan menuturkan tentang brata malam siwa kepada baginda raja. Ini merupakan brata yang paling utama, dalam upaya mencapai sorga dewa Šiwa;

2. Māghāphalgunayer madhye krsnapakse caturdasi śivaratriti vijnnya sarvapāhārini, artinya,
Pada malam ke-14 malam yang paling gelap, di pertengahan bulan Magha (sasih kapitu) atau Phalguna (sasih kawulu), adalah malam Šiwa, yang dapat membebaskan semua desa;

3. Krtopavāsā ye tasyam sivam arcanti jāgratah bilvapatrai caturyamam tayanti śivatulyatām,

artinya,

Mereka yang melaksanakan brata siwaratri; berpuasa, atau upawasa, jagra atau tidak tidur, berbhakti kepada Dewa Šiwa dengan memakai sarana daun bila, semalam suntuk akan mendapatkan anugrah Dewa Siwa;

4. Na tapobhir na daraiç ca na va japyasamādhibhih prāpyate taphalam

rājannopavāsamakhādibhih, artinya,

Bahwa phala brata ini tidak diperoleh dengan kekerasan, tidak juga dengan hadiah-hadiah, semadhi, doa, puasa dan lain-lain;

5. Guhyād gubataram loka vratam otacchivapriyam tvayāpi khalu sarvatrana prakāsyam idam vratam, artinya,

Brata siwaratri sangat rahasia dan tentu saja tidak boleh dibuka di manamana walaupun oleh Tuanku sendiri;

6. Bhüdaranām yathamerus tejasām bhāskaro yatha dvipādam ca yathā viprah kapileva catuspadām, artinya,

Brata malam Šiwa merupakan brata utama, ibaratkan meru-Nya pegunungan, sinarnya matahari, dan guru dari semua makhluk;

7. Japyanām iva gayatri rasānām amratam, yath $\bar{a}$ purusanam yath $\bar{a}$ visruh strinām yadvad arundhati, artinya, 
Doanya mantram Gayatri, amertanya cairan Wisnunya orang laki-laki, Arundhatinya orang wanita;

8. Sivaratrivratam rājan vratānām uttamam tathā sivaratrir mahāvahnir bhavānicasamanvita,

artinya

Malam Šiwa yang diasosiasikan dewa

Bhavani, begitu terjadi kontak, bisa membakar bahan bakarnya dosa, baik basah maupun kering;

9. Dahaty avarito yogãe chuskārdam kalmasedhanam etet tekathitam rājān sivaratrivratam mahat avam eva purā devyai mahādevena bhāsitam, artinya,

Brata agung malam Siwa ini telah diuraikan kepada Tuanku seperti telah diceritakan kepada Dewi sebelumnya oleh Mahadewa'

Inilah esensi rangkaian upacara Šiwaratri, yang bersumber pada sastra Sanskreta. Dapat dipahami bahwa malam siwa atau siwaratri merupakan malam penghormatan Šiwa sebagai manifestasi Tuhan Yang Maha Sempurna. Bagi para peneliti karya sastra kakawin, Karya Mpu Tanakung ini dianggap sebagai karya "trobosan", guna dapat menjadikan manusia biasa, manusia pāpa, hadir dalam suatu kegiatan keagamaan.

\subsection{Skanda Purana}

Naskah Skanda Purana, khususnya pada bagian Kedakarakanda dari Maheswarakanda menguraikan percakapan antara tokoh Lomasa dengan para Resi. Kepada para Rsi, Lomasa bercerita tentang si Canda yang memiliki karakter jahat, sebagai pembunuh segala makhluk, bahkan sampai membunuh brahmana. Inti dari percakapan ini adalah kesadaran akan perbuatannya sebagai pembunuh, telah mengantarkan dirinya akan arti sebuah kebenaran.
Diakhir cerita, Lomansa menjelaskan bahwa, akibat dari perbuatannya, si Canda diceritakan mengerti dan menghayati arti "Kebenaran". Pesan moral yang ingin disampaikan oleh pengarang melalui tokoh Lomansa ini pada bagian Kadakarnakanda ini adalah perbuatan si Canda telah membawa dirinya pada kesadaran akan kebenaran.

Dalam purāna ini juga ditemukan uraian singkat tentang asal mula upacara Śiwaratri, bahwa upacara siwaratri itu bermula dari percakapan antara dewi Parwati dengan Dewa Šiwa.

Dalam percakapan Dewa Siwa dengan dewi Parwati diuraikan pelaksanaan brata Šiwaratri yang utama. Penjelasan siwa kepada Dewi Parwati dimulai dengan memberikan sebuah ilustrasi kisah seorang raja yang berperangai buruk, bernama Sundarasenaka. Kegemaran raja ini adalah berburu, setiap saat pergi ke hutan untuk berburu, dengan dibantu oleh seekor anjing kesayangan. Rangkaian kisah sang raja yang memiliki kegemaran berburu ini pun diuraikan masuk alam siwa setelah melakukan brata Siwaratri pada malam siwa.

Selanjutnya Sudarta, (1991:44) menguraikan delapan tahanpan upacara siwaratri karya Mpu Tanakung dalam teks kakawin siwaratrikalpa yang bersumber dari skanda purana sebagai berikut:

1. Ring eñjing $i$ huwus ning anggelar anusmarana datenga ring gurugreha/manembaha jugāmwitanglekasaken brata sumuhana pāda sang guru/ri sampun ika madyusäsisiga manggelarakena Siwānalārcanal teher duluranupawāsa saha mona manigasana suddhakangsuga/l

Artinya, 
Tahapan pertama pelaksanaan upacara siwaratri dilakukan pada pagi hari. Pada tahapan ini dilakukan pemusatan pikiran ke tempat guru, guna melakukan sembah dengan cara meletakkan kepala di kaki guru, serta memohon ijin untuk melakukan brata siwaratri. Kemudian melakukan pembersihan diri dengan cara mandi, menggosok gigi, setelah terasa bersih dan bahkan terasa tenang,kemudian melakukan sembah kepada api Šiwa. Idealnya hal ini dilakukan setelah melakukan puasa (upawasa) dan tidak berbicara (monabrata).

2. ri sampun $i$ telas nikang rahina ring wengi niyata matang- hya tan mremal bhatāra Šiwalingga kewala sirārcanan $i$ dalem ikang surālayal Kumāra nguniweh Gajendrawadana ng ruhunana sira kapwa püjanen/ rikang rajani yama pat gelarana krama nira manuta ng sakabwatan// artinya,

upawaca dan monobrata hendaknya dilakukan sampai matahari tenggelam, dan bahkan disertai dengan jagra tidak tidur semalam suntuk. Selama ini hendaknya melakukan persembahan hanya kepada Siwalingga yang ada di dunia para dewa, perlu ditegaskan bahwa persembahan kepada siwalingga dilakukan setelah sebelumnya melakukan persembahan kepada dewa Kumara dan Gajendrawadana. Demikianlah sembah yang dilakukan pada tahapan ini, dengan menyertakan sesajian yang secukupnya.

3. menur kanyiri gambir arja kacubung saha waduri putih la- wan putat// asoka saha nāgapuspa hana tangguli bakula kalak macampaka/ saroja biru bang putih sahana ning kusuma halapen ing samangkanal makādi semi ning majārja sulasih panekara ning angarcane sirall

artinya,

berbagai kembang perlu disiapkan ke dalam sesaji seperti: Bunga menuh, kenyiri, gambir arja, kucubung, bunga waduri putih serta putat, juga bunga asoka, nagasari serta tangguli, bakula, kalak dan cempaka, bunga teratai biru, merah dan putih serta segala macam bunga hendaknya dipakai, tetapi yang paling utama adalah pucuk bunga maja dan sulasih yang merupakan aturan orang yang menyembah Siwa

4. lawan sahana ning sugandha pakadhūpa saha ghreta sudipa ring kulem/ ikang caru bubur pehan saha bubur gula liwet acarub hatak wilis/ yateka pinakādi ning caru yadin dulurana phala pāna matsyakal samangkana keta ng kramolahakeneng sawengi saka sayāma tan lupa//

artinya,

lagi pula, segala macam bunga berbau wangi hendaknya dipakai dalam persembahan itu, misalnya: dupa wangi, minyak wagi, dan lampulampu di malam hari; disajikan juga bubur susu dan bubur gula dicampur kacang hijau, semua sesajian yang utama, perlu juga sajian buah-buahan, minuman dan daging, semua ini adalah unsur-unsur sesajian yang harus disiapkan, disajikan sepanjang malam tanpa boleh ditinggalkan.

5. mredangga sahanonyan-unyan asameni kapalalimurārip ing mata/ yadin mangucapa ng kidung rumasana ng kakawin apasang arja len nital sabhāgya keta yan wruhangucapaken Sabarakathana 
ring samangkana/ awas katemu tang padadhika tekap akathana Lubdhakātmaka/l

artinya,

Gambelan Kendang, dan alat musik yang lain perlu dimainkan, guna dapat menjaga gairah pemujaan selain berguna untuk mengusir kantuk; lantunan seni suara seperti kidung atau pembacaan kakawin. Baik sekali mengadakan malam pertunjukan, dan yang tidak boleh ditinggalkan adalah tema pemburu sampai bisa masuk sorga yang paling tinggi.

6. ri moksa nikanang kulem ri teka ning rahina masunga dana ring sabhal suwarna-Šiwalingga dana ri mahādwaja parama susila wedawit/ asing lwira nikang dateng sungana dāna sakawasa hayo jugātulak/ teher kaluputeng turu ri rahinanya sagawaya hayo kurang tutur//

artinya,

saat malam menjelang pagi, dan pagi menjelang siang, bersedekahlah, jadikanlah lingga emas berbentuk Siwa sebagai persembahan kepada para pendeta agung dan suci; tidak perlu dipilih-pilih, bersedekahlah kepada yang datang sebatas kemampuanmu, jangan menolak orang datang, ingat jangan sampai tertidur pada hari itu, jangan gegabah dalam melaksanakan pekerjaan apaun yang menjadi profesi.

7. yadin tan angulah bratāning atutur tan aturu juga kāla mangkanal sakalwiran $i$ jāti ning wwang atuhanwama bini jalu kanyaka kuneng, nyameka musi ring Siwālaya mamukti su-kha tan abalik prih ring hati, sakahyun ika wastu siddhi katekan katemu phala nikāmangun hayu//

artinya,
Walaupun tidak melakukan brata siwaratri, tetapi tetap sadar dan tidak tidur pada malam siwa, tetap terjaga pada malam siwa, akan tetap menikmati phala baik, tanpa memandang keadaan, tua atau muda, wanita atau pria atau gadis; dipastikan akan mencapai sorga Bhatara Šiwa, merasakan kebahagiaan, tanpa kesusahan, sukses daslam cita-cita, sebagaiphala dari perbuatan baik yang diamalkannya.

8. nahan wacana sang hyang Iswara arinya,

Demikianlah penjelasan Dewa Iswara tentang pelaksanaan upacara Siwaratri

\subsection{Siwa Purāṇa}

Serupa dengan purana di atas, pada bagian Jnānasamhita dari Siwa Purāņa menguraikan percakapan antara Suta dengan para Resi. Sedikit berbeda dengan uraian di atas pada bagian ini menguraikan pentingnya ritual upacara Šiwaratri. Sebagai ilustrasi, Suta menceritakan kisah seorang manusia yang amat kejam bernama Rurudruha, sekalipun tidak diuraikan sebagai pembunuh pengarang memakai istilah orang yang kejam. Namun karena tekun dan kusuk melaksanakan brata Šiwaratri, akhirnya kekejaman masa hidupnya, membuatnya dia sadar akan kekejaman dan kedangkalan pikirannya. Kesadaran akan kekejaman inilah yang membuat dirinya menyadari jalan kebenaran

Guna lebih menerangjelaskan teks siwaratrikalpa dari sumber sanskreta, penelusuran dilakukan dalam kepustakaan Jawa Kuno. Penelusuran atas karya siwaratrikalpa pada kepustakaan jawa menemukan bahwa kekawin Šiwaratrikalpa adalah karya Mpu Tanakung. Kakawin ini dibangun oleh 20 macam wirama, dengan jumlah bait sebanyak 232 buah. Karena 
kemahiran Mpu Tanakung dalam olah bahasa dan sastra melahirkan gubahan kisah perjalanan Si Lubdhaka sebagai pemburu, yang berakhir sampai dengan memasuki alam siwa, dengan sangat menarik dan menakjubkan.

Selain gubahan kisah lubdaka yang mempesona, yang tidak kalah menarik dari karya Mpu Tanakung adalah uraian pelaksanaan upacara siwaratri yang cukup mendasar nan sangat indah. Jika dikaitkan dengan gubahan siwaratri pada Padmapurāna, dapat dipahami bahwa teks padmapurana bersifat didaktik tanpa suatu pretensi estetis, sedangkan kakawin Siwaratrikalpa adalah teks didaktik yang mempunyai pretensi estetis. Melalui perbandingan ini dapat diketahui bahwa karya Mpu Tanakung jauh lebih estetis, dan sengaja dibuat agar karya sastra siwartri yang digubahnya lebih menarik dan bertahan sepanjang masa di hati pembacanya. Melalui metode semiotik.

Mpu Tanakung cukup sukses menyebarkan nilai-nilai agama, yaitu dengan memanfaatkan media sastra (kakawin) yang digemari oleh masyarakat. Terkait hal ini, Prof. Zoetmulder menyatakàn, Mpu Tanakung telah membuktikan, bahwa dirinya merupakan ahli bercerita dan seorang pengamat yang cermat. Ia menguasai gaya kakawin dengan mendalam tanpa melebih-lebihkan atau membuat-buat" (1974).

Selain gubahan cerita Lubdaka yang manarik, dan paparan upacara siwaratri yang mendasar, Mpu Tanakung juga menunjukan diri sebagai maha kawi yang ulung. Hal ini dibuktikan dengan ditemukannya buku kakawin karya beliau yang menguraikan tentang pedoman cara menulis kakawin, yang cukup populer pada jaman Majapahit akhir. Tiga hal ini, gubahan yang menarik, paparan upacara siwaratri yang mendasar, dan karya sastra kakawin yang bagus dan indah, membuat karya karya Mpu Tanakung bernilai universal sepanjang jaman.

\subsection{Kakawin Siwaratrikalpa}

Di tengah kejayaan karya Kakawin Siwaratrikalpa, ditemui pendangan negatif atas kehadiran Kakawin Siwaratrikalpa karya Mpu Tanakung. Y.B. Mangunwijaya dalam bukunya berjudul Sastra dan Religionitas, yang terbit pada tahun 1982, memandang, dan bahkan menuduh Mpu Tanakung dengan mangatakan sebagai penjilat Ken Arok. Logika ini diambil dari pembacaan kelahiran cerita Lubdaka carita bertepatan pada masa pemerintahan raja Ken Arok. Y.B. Mangunwijaya menulis, "karya sastra Lubdhaka yang digubah oleh Mpu Tanakung, yang hidup selama pemerintahan Ken Angrok, ketika kraton dipindah dari Kediri ke Tumapel, tahun Saka 1144 (1222 sesudah Masehi). Kesamaan karakter raja Ken Arok dengan tokoh Lubdaka dalam cerita Lubdaka, sebagai pembunuh sangat dimungkin bisa masuk sorga manakala melakukan brata siwaratri. Atas dasar logikaseperti ini kemudian kehadiran Lubdakan carita karya Mpu Tanakung dimaknai untuk kepentingan mengambil hati raja Ken Arok.

Y.B. Mangunwijaya menjelaskan,bahwa tuduhan trhadap Mpu Tanakung sebagai penjilat kan Arok diambil dari buku Kepustakaan Djawa, karya R. Ng. Poerbatjaraka 1962. Tuduhan miring sebagai penjilat, sangat terkait karena dalam kontek suasana kerajaan dianggap dapat melegitimasi Raja Girindrawangsaja alias Ken Arok, 
yang digambarkan berkarakter kejam dan bengis, seringkali memakai garong dan pembunuh.

Pewartaan tuduhan Mpu Tanakung sebagai penjilat raja Ken Arok menìmbulkan kemasgulan hati para pencinta kakawin, mengingat kakawan siwaratrikalpa ini merupakan karya sastra kakawin yang dipandang memiliki nilai kesucian. Para tokoh dan sastrawan jawa kuno memandang perlu mengadakan pembelaan atas tuduhan.

Salah seorang peneliti kakawin bernama Prof. A. Teeuw menyatakan, bahwa kakawin Siwaratrikalpa ditulis sekitar tahun 1466: 18; dua ratus lima puluh tahun pasca pemeritahan raja Ken Arok. Penelitian yang dilakukan atas dua prasasti, yakni prasasti Waringinpitu berangka tahun $1447 \mathrm{M}$, dan prasasti Pamintihan berangka tahun 1473, memperoleh pemahaman bahwa dua prasasti ini dikeluarkan oleh raja Majapahit bernama Singhawikrama dengan nama kecilnya Suraprabhawa. Hal ini dengan jelas dapat dibaca pada manggala kakawin Siwaratrikalpa,ditulis, .../manggeh denyan rahaywa sang panikelan tanah anulusa katwang ing prajal tan lyan śry Adi-Suraprabhawa sira bhupati saphala Girindrawangsaja//2,c dan d). Dengan munculnya hasil penelitian yang dilakukan oleh Teeuw melahirkan pandangan yang menyatakan bahwa lahirnya kakawin siwaratrikalpa dua setengah abad setelah raja ken arok, maka gugurlah kecurigaan yang menyatakan bahwa gubahan kakawin siwaratrikalpa yang dilakukan oleh Mpu Tanakung untuk tujuan mengambil hati Ken Arok tidak didukung oleh bukti bukti yang masuk akal.

Pada tahun 1962, Prof. Zoetmulder telah mengajukan pendapat baru dari hasil penelitiannya terhadap prasasti Waringin Pitu, dan Pamintahan yang dibandingkannya dengan manggala kakawin Siwaratrikalpa, tentang kapan Mpu Tanakung hidup dan mengarang kakawin Siwaratrikalpa tersebut. Dalam makalah berjudul "Djaman Mpu Tanakung", disajikan dalam Kongres Ilmu Pengetahuan 2 yang diadakan pada tahun 1962, Zoetmulder menyatakan bahwa kakawin Siwaratrikalpa ditulis pada kwartal ke-3 abad ke-15, atau pada jaman Majapahit akhir.

Prof. A. Teeuw (1969) yang juga meneliti bahasa kakawin tersebut dengan lebih tegas menyatakan bahwa kakawin Siwaratrikalpa ditulis antara tahun 1466 - 1478 M. Jadi sekitar dua setengah abad sejak pemerintahan Ken Arok. "Sejauh saya tahu hanya dalam kakawin ini seorang penulis biasa ditampilkan sebagai tokoh utama", Sarjana ini juga mengakui Mpu Tanakung mempunyai kemampuan yang tidak tertandingi dalam melukiskan suatu adegan "polos atau tidak dibuat-buat". Jasa Mpu Tanakung dalam kaitannya dengan karyanya ini lebih terdapat dalam cara ia menggubah cerita daripada menemukannya. Cerita ini terdapat dalam berbagai purāņa yang masingmasing berbeda-beda, kadang-kadang dengan cukup jauh, khususnya mengenai adegan-adegan yang terjadi di bumi.

\section{SIMPULAN}

Tek kakawin siwaratrikalpa bersumber Sanskreta khususnya dari Padma Purana, yang memiliki relevansi dengan beberapa purana yang lain seperti: Šiwa Purāna, Skanda Purāna dan Garuda Purāna. Logika didaktis tokoh jahat seperti Lubdaka, yang kemudian bisa mencapai alam siwa bersifat 
kontradiksi dengan logika ajaran kaarma Phala. Guna menghindari kontradiksi paradigma logika ini, pengarang membedakan istilah papa, dalam teks dengan cara tidak pernah menyebut dosa. Istilah papa berbeda dengan istilah dosa. Dosa adalah predikat bagi orang yang melakukan kesalahan; sedangkan papa adalah predikat bagi orang yang hina. Lubdaka adalah orang papa. Pengarang tidak memakai istilah dosa untuk Lubdaka, yang hidup sebagai seorang pemburu. Dharma seorang pemburu adalah membunuh binatang buruan. Ini tidak dosa,

\section{Pada Šiwa Purāna, Skanda} Purāna dan Garuda Purāna tidak dibedakan secara pasti antara Papa dan dosa, bahkan seakan disamakan, sama sama menjadi batu loncatan untuk mencapai kesadaran diri yang berujung pada kebenaran. Kesadaran orang akan papa dan dosa dapat mengantarkan orang pada pertobatan; meninggalakan jalan yang salah dan kembali pada jalan kebenaran.

$\begin{array}{ccr}\text { Pandangan negatif } & \begin{array}{r}\text { tentang } \\ \text { kakawin }\end{array}\end{array}$

siwaratrikalpa untuk tujuan mengambil hati Raja Ken Arok oleh YB Mangunwijara dalam buku Sastra dan Religiusitas, terbantahkan oleh penelitian Teeuw, yang mengatakan bahwa terbitnya karya sastra kakawin oleh Mpu Tanakung dua setengah abad pasca pemerintahan raja Ken Arok.

\section{DAFTAR PUSTAKA}

Mangunwijaya, YB, 1995. Sastra dan Religiusitas, Jakarta: Gramedia.

Poerbatjaraka, Prof. Dr. R. Ng. 1952. Kapustakan Djawa. 1952. Jumantara Vol. 2 No.1 Tahun 1952 Djambatan

Teeuw, A. dan Th.P. Galestin, S.O. Robson, P.J. Worsley, P.J. Zoetmulder 1969, Siwaratrikalpa of mpu Tanakung. The Hague: Martinus Nijhoff

Zoetmulder, P.J. (1962). Sastra Jawa Kuno Selayang Pandang. Jakarta: Djambatan 